\title{
A KKV-szegmens hitelezési folyamatainak elemzése a hitelgaranciák tükrében, az Európai Unióban*
}

\author{
Balog Ádám
}

2011 óta a finanszírozás mint probléma az ECB SAFE felmérése alapján jelentősen hátrább került a KKV-k legnyomasztóbb kihivásainak rangsorában. A fejlett piaci jegybankok támogató monetáris politikája, illetve ezzel párhuzamosan az alacsony kamatkörnyezet is közrejátszott abban, hogy 2010 óta globálisan jelentősen enyhültek a forrásbevonás kondíciói. Az EU-ban a kis- és középvállalati forrásbevonás 80-85 százaléka bankhiteleken keresztül valósul meg, magában hordozva így azt a veszélyt, hogy egy esetleges pénzügyi turbulencia esetén a vállalatok forrásbevonási lehetőségei szükülnek, ami kockázatot jelent a produktivitás alakulását illetően. Az ilyen tendenciák hatásának tompítására fontos eszköz a hitelgarancia szerepének növelése, amelynek keretében a pénzintézetek nagyobb biztonsággal és alacsonyabb kockázattal tudják forrással segíteni a KKV-szektort recesszió esetében.

Journal of Economic Literature (JEL) kódok: E32, G15, G21, O16, 019

Kulcsszavak: hitelgarancia, KKV, bankrendszer

\section{Az európai KKV-szektor és finanszírozásának helyzete}

Az Európai Bizottság szabályrendszere alapján a kis- és középvállalatokat a következőképpen rangsorolhatjuk (1. táblázat):

1. táblázat

Az EU definíciója a kis és közepes vállalatokra

\begin{tabular}{c|c|c|c} 
Méret & Foglalkoztatott (fő) & Forgalom & Mérleg \\
\hline Mikro & $<10$ & $<€ 2$ millió & $<€ 2$ millió \\
\hline Kis & $<50$ & $<€ 10$ millió & $<€ 10$ millió \\
\hline Közepes & $<250$ & $<€ 50$ millió & $<€ 43$ millió \\
\hline
\end{tabular}

Forrás: Európai Bizottság ${ }^{1}$

* Jelen cikk a szerző nézeteit tartalmazza, és nem feltétlenül tükrözi a Magyar Nemzeti Bank hivatalos álláspontját.

Balog Ádám az MKB Bank Zrt. vezérigazgatója. E-mail: balog.adam@mkb.hu

A magyar nyelvű kézirat első változata 2017. szeptember 22-én érkezett szerkesztőségünkbe.

DOI: http://doi.org/10.25201/HSZ.17.1.6282

${ }^{1}$ KKV-definíció: http://ec.europa.eu/growth/smes/business-friendly-environment/sme-definition_hu. Letöltés ideje: 2017. május 5. 
A kis- és középvállalatok (KKV-k) csoportjába tartozik minden 250 főnél kevesebbet foglalkoztató és éves 50 millió euró árbevétel alatti társaság. Az Európai Unióban ezek a társaságok az ipar, építőipar és a kereskedelem szegmensében dominánsak, amelyek egyben a legtőkeigényesebb szektorok is; ezért a társaságok finanszírozásának fenntartása kiemelten fontos nemcsak a saját növekedésük, múködésük szempontjából, hanem az egész gazdaságot figyelembe véve is. Az 1. ábrán látható, hogy a tőkeáttétel a legmagasabb a fent említett szektorokban, így a kamatok változására és a gazdasági ciklusok változására ezek az iparágak a legérzékenyebbek. Mivel a magasabb tőkeáttétellel múködő cégek között jelentős a KKV-k aránya, valamint ezek a szektorok (például az építőipar) erős korrelációban állnak a GDP változásával, illetve jelentősen hat rájuk a fogyasztás alakulása (kis- és nagykereskedelem), kulcskérdés, hogy a finanszírozásuk milyen formában valósul meg.

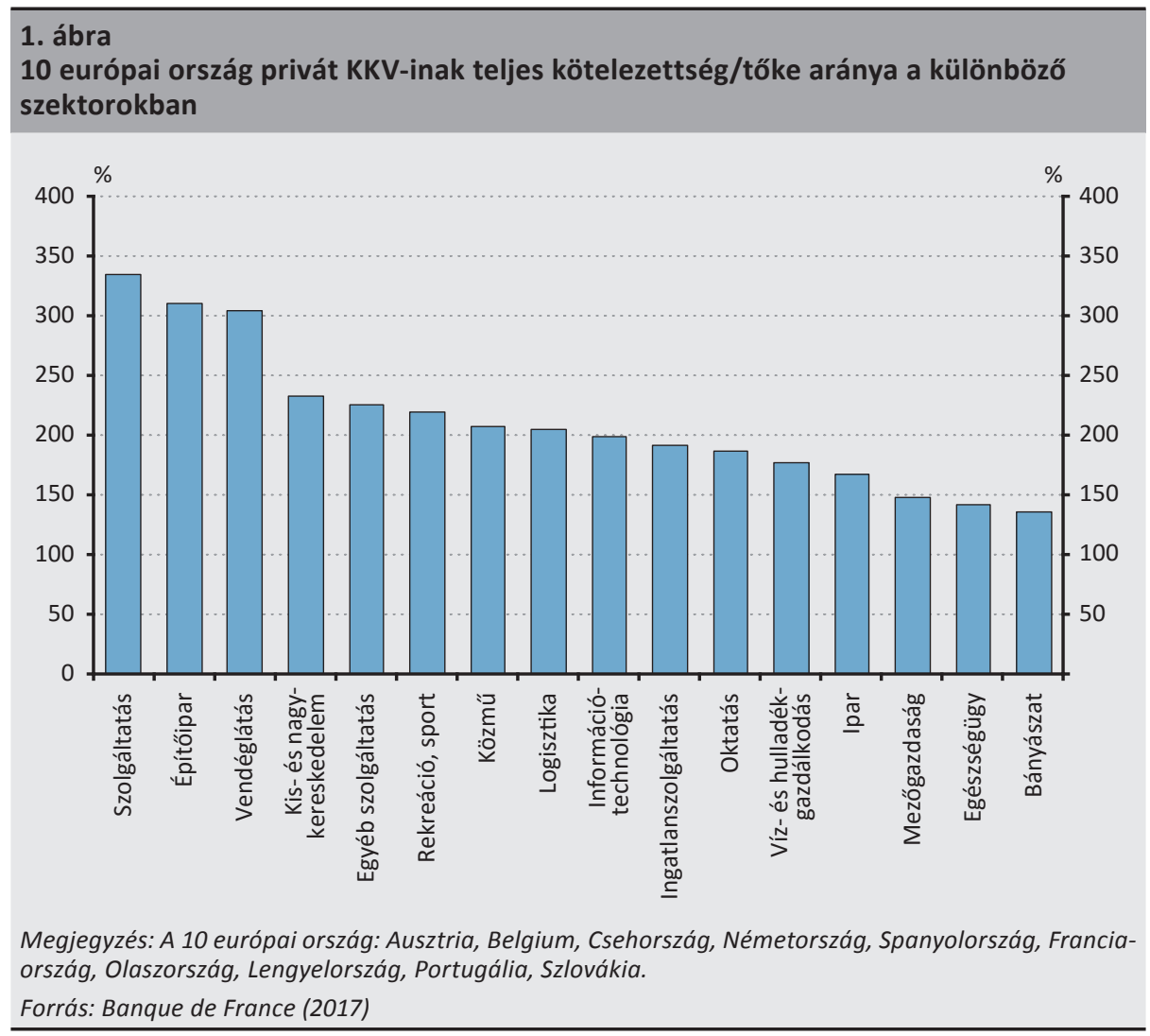

Az Európai Unióban a KKV-k forrásbevonásuk 80-85 százalékát bankhiteleken keresztül valósítják meg. Ez pont ellentétes az Amerikai Egyesült Államokban (USA) megfigyelt gyakorlattal, ahol a hasonló társaságok 80-85 százalékban a tőkepiacokról szerzik a forrásaikat (WSBI-ESBG 2015). Ennek legfontosabb formáit a vállalati 
kötvények, private equity, venture capital, crowdfunding vagy hibrid megoldások jelentik (Firoozmand et al. 2015). A vállalati kötvények tekintetében a 2000-es évek közepéhez viszonyítva jelentősen csökkent a kibocsátás mind az EU, mind az USA vonatkozásában. Az Európai Központi Bank adatai szerint 2017 szeptemberéig 50 milliárd eurónyi vállalati kötvényt bocsátottak ki a nem pénzügyi intézmények. Öszszehasonlításképpen az Egyesült Államokban szeptemberig bezáróan 1100 milliárd dollárnyi értékpapír (vállalati kötvény) került a piacokra.

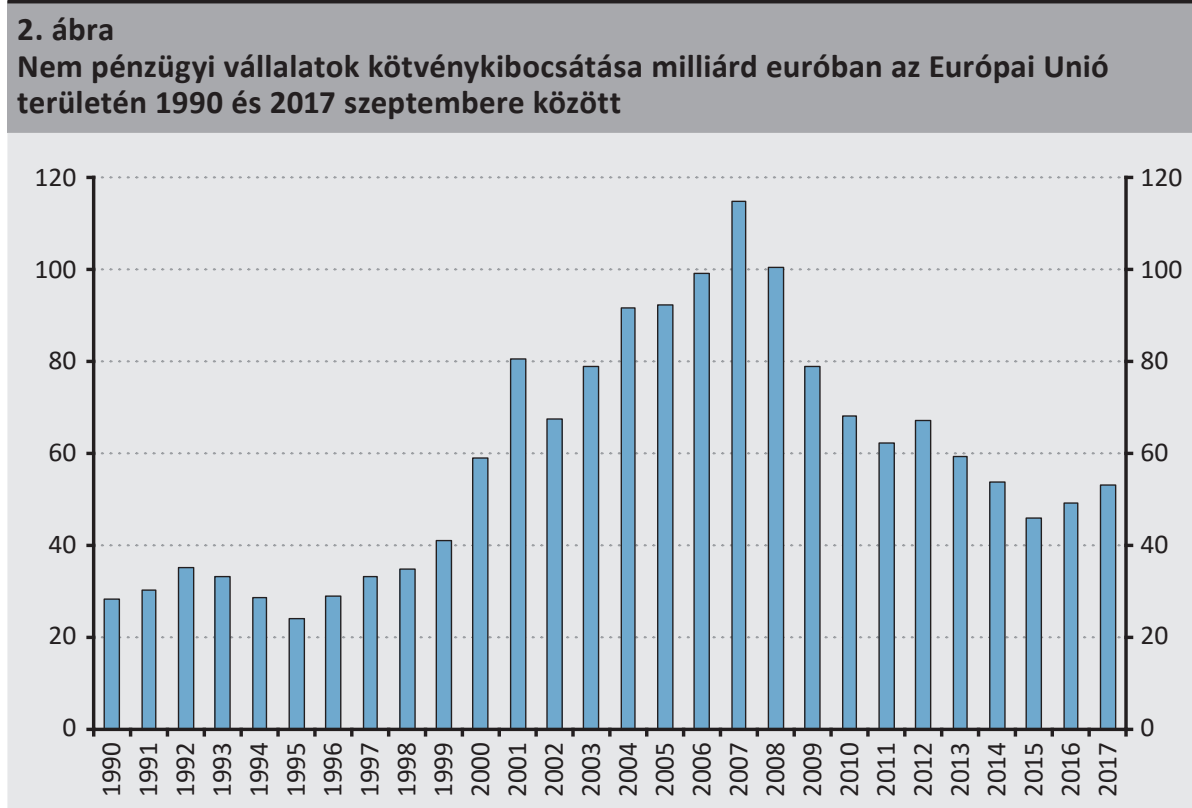

Forrás: Európai Központi Bank (ECB 2017b)

Az EU-ban a gazdaság alakulása szempontjából a KKV-k jelentős szerepet játszanak, mert a kontinens GDP-jének 60 százalékát adják, és kb. 90-100 millió főt foglalkoztatnak, ami a munkaerő-állomány körülbelül 70 százaléka. Jelenleg 22 millió kis- és közepes vállalat múködik az EU-ban. Amennyiben ezek a társaságok nem jutnak forráshoz a megfelelő mennyiségben és struktúrában, úgy mindez a beruházások csökkenését, a vállalatfelvásárlások elmaradását és csökkenő innovációt vonhat maga után. A hitelezési aktivitás az intenzívebb beruházási tevékenységen keresztül járul hozzá a gazdasági növekedéshez. A megfelelő külső finanszírozás révén növekedhet a vállalkozói kedv, újabb vállalkozásokat alapíthatnak, valamint javulhat a cégek mérethatékonysága is. A gazdasági ciklus felívelő szakaszában a kockázatokat mind a hitelfelvevők, mind a hitelnyújtók alacsonyabbnak ítélik meg a javuló munkaerőpiaci helyzetnek, a fogyasztási kedv javulásának köszönhetően. A vállalatok 
a profitjuk rövid távú ingadozását tompíthatják külső finanszírozás által, mindez a beruházások mérsékeltebb változékonyságát eredményezheti (Bodnár et al. 2014).

Utóbbi esetében fontos kitétel, hogy a piaci szereplők a visszaesés átmenetiségében higgyenek. Amennyiben az üzleti ciklus kifullad, az a vállalatok aktivitásának csökkenéséhez, a profitok mérsékléséhez és így a munkanélküliség növekedéséhez, a fogyasztás csökkenéséhez vezethet. Mindez növeli a kockázatot, és a szerepelők mérsékeltebb aktivitását eredményezi. Mivel ez egy spirális folyamattá is válhat, a beavatkozás, illetve a ciklusok volatilitásának simítása kiemelt fontossággal bír.

A 2008-as válság óta a jegybankok nulla közeli kamatpolitikájának és egyéb intézkedéseknek köszönhetően az KKV-k finanszírozási lehetőségei megfelelőek (3. ábra), az kikerült a szektor legégetőbb problémái közül (ECB 2017a). Ez nem volt mindig így: 2008-ban és 2011-ben a finanszírozási nehézségek bizonyultak a harmadik (sőt, az egyéb kategóriát nem számítva a második) legnagyobb problémának az európai KKV-k életében, azóta viszont már megelőzte a munkaerő költsége, a nem szakképzett munkaerő hiánya és az adott iparág szabályainak betartása, bonyolultsága is.

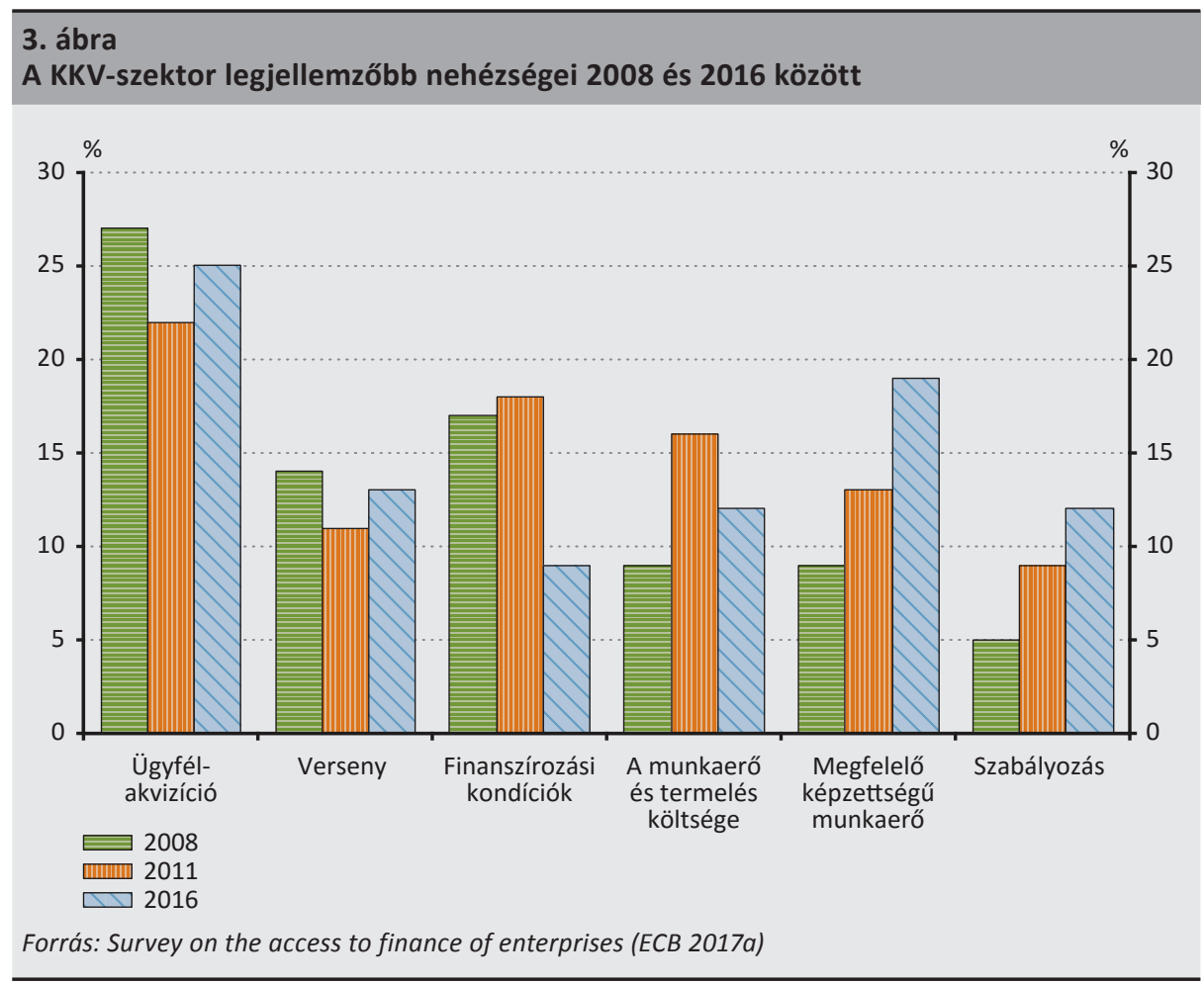


A gazdasági recesszió és a hitelhez, forráshoz jutás nehézsége általában egymást követik, sőt egymást erősíthetik. Azonban a gazdasági visszaesés mihamarabbi orvoslása érdekében éppen ez az az időszak, amikor olyan anticiklikus intézkedések szükségesek, amelyek segítségével tompítható a visszaesés hatása.

A monetáris lazítás és a zéró kamatpolitika is ezt a célt szolgálta a 2007-2008-as válságot követően, igaz, a piac fejlettségétől függően a különböző országokban más és más módon érte el a kívánt hatást. Mivel az Európai Unióban sokkal fajsúlyosabb a bankhitel, ezért a recessziós időszakban a hitelezést erősítő intézkedéseknek pozitív hatása lehet az egész kontinens gazdasági helyzetére.

A KKV-k hitelfelvételéhez kapcsolódó garanciaprogramok célja, hogy olyan cégek is hitelhez jussanak, amelyek múltjuk miatt, vagy nem megfelelő fedezetük miatt erre nem lennének alkalmasak. Ezenkívül a garanciaprogramok a gazdasági ciklusok alján is biztosíthatják a KKV-k forráshoz jutását, így pozitívan hathatnak a GDP-re, esetleg tompíthatják a visszaesés mértékét. Az országok határain belül múködő garanciaintézmények felméréséből is az derül ki, hogy ők maguk is működésük szempontjából a KKV-szektor számára nyújtott hitelek garanciájában látják a legnagyobb potenciált, egy friss felmérésben 71 százalékuk válaszolt így (Chatzouz et al. 2017). Fontos szempont lehet az is, hogy a vállalkozók nagy része kevesebb tőkét tud biztosítani vállalkozása számára, mint amennyit szeretne (Evans - Jovanovic 1989).

Az Európai Központi Bank (ECB 2017a) SAFE-elemzése nyolc olyan faktort említ, amely nagyban befolyásolja a hitelkeresletet és -kínálatot. Ezek mindegyike javult az utóbbi években, de a megkérdezett KKV-k szerint a gazdasági környezet és kilátások csak 2017 első felében váltak kedvezővé, és a hitelgaranciák elérhetősége továbbra is negatív megítélésú, és nem is igazán változott 2015 óta. Nagy javulás látható az egyedi, cégspecifikus kilátásokban, valamint a bankok, kereskedelmi partnerek és a külső befektetők finanszírozási hajlandóságában (lásd 4. ábra). A megkérdezett KKV-k szerint a hitelgaranciák kondíciói nem javultak az utóbbi időszakban, ami arra enged következtetni, hogy a társaságok alkalmaznák ezt a lehetőséget, de azok megléte, feltétele nem megfelelő. 


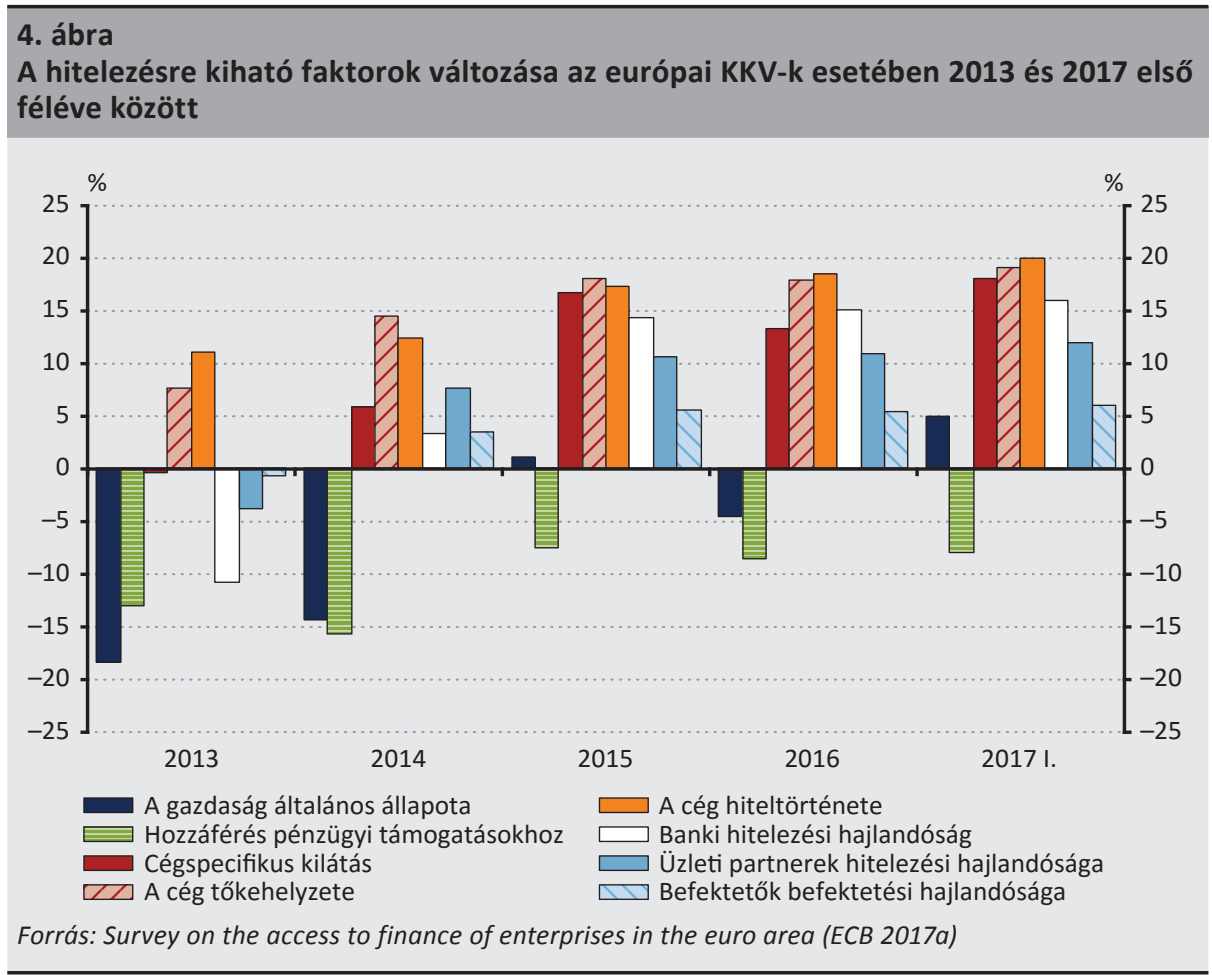

\section{A KKV típusai régiók szerint}

Az egyes országokban fellelhető garanciaprogramok azért fontosak, mert bár van törekvés a helyzet uniós szintű kezelésére, a különböző régiókban más és más típusú KKV-kal találkozhatunk (Moritz et al. 2015). Alapvetően hat csoportot tudunk megkülönböztetni (2. táblázat),

1. változó finanszírozású társaságok, ahol a KKV-k a finanszírozás széles skáláját használják, és ők alkotják a második legnagyobb csoportot (a teljes állomány 16,7 százaléka). Családi, baráti kölcsönöket, eredménytartalékot és hitelt is alkalmaznak finanszírozás tekintetében. Leginkább az építőipart jellemzi, és az átlagosnál magasabb az innovációjuk. Fóleg az északi régiókban találni ilyen vállalatokat.

2. Az államilag támogatott KKV-k leginkább államilag támogatott hitellel rendelkeznek. A teljes KKV-állomány mindössze 7,2 százaléka található itt. Kis és közepes, általában családi cégek, amelyik a déli régiókban elterjedtek, és az iparban domináns a jelenlétük.

3. A hitelből finanszírozott KKV szinte csak banki hitelekre támaszkodik. Alacsony növekedés, alacsony innováció jellemzi a csoportot, amely a teljes szektor 16,1 
százalékát fedi le. Jellemző a rövid futamidejű kölcsön és a forgóeszköz-hitel. Szintén a déli régióban jellemzők.

4. A rugalmasan finanszírozott KKV-szektor 13,2 százalékot tesz ki, és inkább kereskedelmi hitellel, folyószámlahitellel rendelkeznek. Általában mikrovállalkozások egy tulajdonossal, és a nyugati régiókban jellemzők. Átlagos növekedésűek és általában alacsony a forgalmuk.

5. A kereskedelmi hitellel finanszírozott KKV-k a szektor 15,3 százalékát fedik le. Általában kisvállalatok családi tulajdonnal és alacsony növekedéssel és kereskedelmi szektor kitettséggel.

6. Belső finanszírozású KKV-k, amelyek leginkább a keleti régióban és a posztkommunista országokban jellemzők, általában belső finanszírozásból oldják meg a likviditási problémákat (például: eredménytartalék). Ez a legnagyobb csoport a maga 31,4 százalékával. Fiatal, általában családi cégek alkotják ezt a halmazt, amelyek leginkább a szolgáltató szektorban tevékenykednek.

2. táblázat

Az európai KKV-k klaszteranalízise finanszírozásuk szerint

\begin{tabular}{|c|c|c|c|c|c|c|}
\hline A finanszírozás forrása & $\begin{array}{l}\text { Változó } \\
\text { finanszírozású } \\
\text { KKV }\end{array}$ & $\begin{array}{c}\text { Államilag } \\
\text { támogatott } \\
\text { KKV }\end{array}$ & $\begin{array}{c}\text { Hitelböl } \\
\text { finanszírozott } \\
\text { KKV }\end{array}$ & $\begin{array}{c}\text { Rugalmasan } \\
\text { finanszírozott } \\
\text { KKV }\end{array}$ & $\begin{array}{l}\text { Kereskedelmi } \\
\text { hitellel } \\
\text { finanszírozott } \\
\text { KKV }\end{array}$ & $\begin{array}{c}\text { Belső } \\
\text { finanszírozású } \\
\text { KKV }\end{array}$ \\
\hline Eredménytartalék & $28 \%$ & $23 \%$ & $21 \%$ & $15 \%$ & $26 \%$ & $14 \%$ \\
\hline Támogatott hitel & $15 \%$ & $100 \%$ & $2 \%$ & $0 \%$ & $2 \%$ & $0 \%$ \\
\hline Folyószámlahitel & $45 \%$ & $54 \%$ & $56 \%$ & $100 \%$ & $6 \%$ & $0 \%$ \\
\hline Banki hitel & $36 \%$ & $55 \%$ & $95 \%$ & $0 \%$ & $0 \%$ & $0 \%$ \\
\hline Kereskedelmi hitel & $41 \%$ & $32 \%$ & $41 \%$ & $21 \%$ & $70 \%$ & $0 \%$ \\
\hline Egyéb hitel & $73 \%$ & $1 \%$ & $0 \%$ & $0 \%$ & $0 \%$ & $0 \%$ \\
\hline Lízing & $28 \%$ & $24 \%$ & $30 \%$ & $20 \%$ & $41 \%$ & $0 \%$ \\
\hline Tóke & $24 \%$ & $4 \%$ & $0 \%$ & $0 \%$ & $0 \%$ & $0 \%$ \\
\hline Egyéb (pl: kötvény) & $17 \%$ & $0 \%$ & $0 \%$ & $0 \%$ & $0 \%$ & $0 \%$ \\
\hline Nincs külső finanszírozás & $0 \%$ & $0 \%$ & $0 \%$ & $0 \%$ & $0 \%$ & $100 \%$ \\
\hline KKV-k száma a csoportban & 2060 & 887 & 1981 & 1627 & 1888 & 3869 \\
\hline A csoport aránya & $16,7 \%$ & $7,2 \%$ & $16,1 \%$ & $13,2 \%$ & $15,3 \%$ & $31,4 \%$ \\
\hline
\end{tabular}

Forrás: ECB (2017a) és Moritz et al. (2015: 25)

Ahogy a 2. táblázat is mutatja, az egyes klaszterek között van átfedés, azok nem különülnek el élesen. A legtöbb társaság a felvázolt kilenc finanszírozási formából legalább négyet használ (kivéve a belső finanszírozású KKV-k). 


\begin{tabular}{l} 
3. táblázat \\
Az európai KKV-k geográfiai megoszlása a finanszírozásuk szerint \\
\begin{tabular}{c|c|c|c|c|c|c} 
& $\begin{array}{c}\text { Változó } \\
\text { finanszírozású }\end{array}$ & $\begin{array}{c}\text { Államilag } \\
\text { támogatott }\end{array}$ & $\begin{array}{c}\text { Hitelből } \\
\text { finanszírozott }\end{array}$ & $\begin{array}{c}\text { Rugalmasan } \\
\text { finanszírozott }\end{array}$ & $\begin{array}{c}\text { Kereskedelmi } \\
\text { hitel }\end{array}$ & $\begin{array}{c}\text { Belső } \\
\text { finanszírozású }\end{array}$ \\
\hline Kelet-Európa & $14,4 \%$ & $6,3 \%$ & $11,4 \%$ & $9,8 \%$ & $12,3 \%$ & $45,8 \%$ \\
\hline Észak-Európa & $23,7 \%$ & $3,5 \%$ & $11,2 \%$ & $11,6 \%$ & $22,6 \%$ & $27,4 \%$ \\
\hline Dél-Európa & $16,1 \%$ & $9,8 \%$ & $17,3 \%$ & $12,4 \%$ & $17,5 \%$ & $26,8 \%$ \\
\hline $\begin{array}{c}\text { Nyugat- } \\
\text { Európa }\end{array}$ & $15,6 \%$ & $6,2 \%$ & $20,2 \%$ & $17,4 \%$ & $10,8 \%$ & $29,8 \%$ \\
\hline Forrás: Moritz et al. (2015:25)
\end{tabular} \\
\hline
\end{tabular}

A geográfiai megoszlás szerint (lásd 3. táblázat), míg például Kelet-Európában a belső finanszírozású KKV-k vannak túlnyomó többségben (a teljes KKV-állomány 45,8 százaléka tartozik ide), addig Észak-Európa kiegyensúlyozottabb, mert az előbb említett csoportnak 27,4 százalékos részaránya van. Ezt a változó finanszírozású társaságok csoportja követi (23,7 százalék), majd a kereskedelmi hitellel finanszírozott cégek jönnek a sorban (22,6 százalék). Európa déli részén az államilag támogatott társaságok aránya magasabb, mint általában az Európai Unióban. Nyugat-Európát a belső finanszírozású és hitelből finanszírozott KKV-k jellemzik.

Az eloszlásból több dologra is következtetni lehet, így például nyugaton és északon erősebb, fejlettebb a bankrendszer, ezért a hitellel történő finanszírozás és ezzel együtt az állam kisebb szerepvállalása domináns. Egyéb elemzések szerint az olyan régióban, ahol a bankszektor fejlettebb, a vállalatok nagyobb eséllyel használják a kereskedelmi hiteleket. A változó finanszírozású cégek magas aránya az adott régió tőkepiacának fejlettségére utal, igaz ez nyugaton is így van (fejlettebb tőkepiac), mégis itt nem különbözik szignifikánsan az ilyen társaságok aránya az átlagtól (15,6 százalék szemben a 16,7 százalék összes adattal). A változó finanszírozás esetén már megfigyelhető a tőkepiaci finanszírozás, azaz részvény és vállalati kötvény formájában is be tudnak vonni forrást a társaságok.

További egyediségre mutat rá a déli államokban megfigyelhető, az átlagnál magasabb állami szerepvállalás. Olaszország, Spanyolország, Görögország és Portugália esetében a válság óta nem minden esetben sikerült a banki, rossz hiteleket rendezni, így az állam szerepvállalása jelentősebb.

Európa keleti részén a kimagasló belső finanszírozás annak köszönhető, hogy a posztszovjet országok banki szektora és tőkepiaca fejletlenebb, mint Nyugat-Európáé. Ilyen helyzetben sokkal nehezebb külső finanszírozást (bankhitel, kereskedelmi hitel) igénybe venni, így a társaságok nagy része a családra, ismerősökre, illetve a korábban megtermelt nyereségre hagyatkozik. Fontos azonban, hogy hosszú távon a pénzügyi fejlettség javulása növeli a potenciális növekedést, de ez csak egy 
megadott szintig igaz. A túl nagyra nőtt pénzügyi rendszer nem eredményez pozitív hatást (Cecchetti-Kharroubi 2012; Arcand et al. 2012).

A válság által komolyabban sújtott országok is más képet mutatnak. Jelentős viszszaesés volt 2008 óta a déli országokban, így itt a bankok csökkentették kockázatos eszközeiket, és jelentősen romlottak a vállalatok hitelhez jutási feltételei, valamint nőttek a működési költségek is. Ebből kifolyólag az ilyen régiókban lévő cégek inkább a kereskedelmi hitelekre és az állami támogatásra támaszkodtak. Elemzések szerint az állami szerepvállalásnak pozitív hatása van a vállalatok forráshoz jutásában. Nagy-Britannia esetében az olyan KKV-k, amelyek nem voltak sikeresek állami forráshoz jutásban, nehezebben jutottak piaci alapon is külső forráshoz (Murray - Lott 1993). Ugyanez a megállapítás érvényes az USA KKV-szektorára is (Mina et al. 2005; 2013). Államilag támogatott vállalatok könnyebben jutnak intézményi forráshoz még abban az esetben is, ha az általános pénzügyi helyzet nem optimális. Meg kell említeni továbbá, hogy amennyiben a hitelezés szúkül, a vállalatok egyre nagyobb arányban fordulnak egyéb finanszírozási formákhoz, mint amilyen a faktoring vagy a lízing (Moritz et al. 2015), hiszen a visszaeső hitelkínálatot szeretnék kiváltani. Ebben lehet segítségükre a hitelgarancia intézménye.

\section{A külső finanszírozást érintő anomáliák}

A gazdasági turbulenciáktól eltekintve a bankok nagy része akkor is vonakodik hitelt adni a KKV-k bizonyos részének, ha egyébként a gazdaság megfelelően prosperál. Ennek oka, hogy a többnyire fiatal társaságok hitelképességére vonatkozó információk megszerzése drága vagy szinte lehetetlen a releváns adatok hiánya miatt. Ebben az esetben a regionális bankok mint a regionális társaságok jobb ismerői is bizonyos fokig megoldást jelenthetnek (Lang et al. 2016). További hátrány, hogy e társaságoknak nincs olyan jellegú eszköze, amely a hitel fedezetéül szolgálhatna. Így sok KKV, amely egyébként megfelelő és életképes projekttel, fejlesztéssel rendelkezik, azt a finanszírozás hiánya miatt nem tudja megvalósítani.

Ez utóbbira általában úgy hivatkoznak, mint a KKV-k finanszírozási rése („financing gap"), amely szerint a nem hatékony külső finanszírozási források hiányának oka az információs aszimmetria (Chatzouz et al. 2017). Ez az aszimmetria nem megfelelő hitelfelvevők kiválasztásához is vezethet, amikor a bank nem tudja megkülönböztetni a jó és rossz projekteket, illetve a bank, mivel nincs megfelelő mennyiségú és minőségű információja az adott KKV-ről, magasabb hitelkamatot állapít meg (Pozzolo 2004). Stiglitz et al. (1981) elemzése szerint a KKV-k alacsony transzparenciája, nem megfelelő fedezetei növelték az információs aszimmetriát és az ebből fakadó kockázatokat (moral hazard). Néhány országban ez volt az egyik ösztönző arra, hogy létrehozzák a hitelgarancia intézményét. Az erkölcsi problémakörrel is találkozhatunk, hiszen a csőd esetében fennálló korlátozott felelősség extra kockázatvállalásra 
bátoríthatja a hitelfelvevőket (Farhi - Tirole 2011; Holmstrom - Tirole 1997; Kuniyoshi - Tsuruta 2014).

A hitel fedezetéül szolgáló biztosíték sem minden esetben megfelelő a hitelfelvétel során. Egyrészt a kisebb vállalkozások nem minden esetben tudnak megfelelő biztosítékot nyújtani, másrészt az is valós probléma, hogy a fedezet a vállalkozásnak általában többet ér, mint a banknak. Az Európai Központi Bank és az Európai Bizottság felmérése szerint (2016 második félév) a megfelelő fedezet hiánya az egyik oka annak, hogy a KKV-k nem jutnak megfelelő külső forráshoz. Míg nagyvállalatok esetén az esetek mindössze 0,5 százalékában hivatkoztak a nem megfelelő fedezetre mint tényezőre, addig ez a KKV-k esetében ez az érték 5 százalék volt. A hitel biztosítéka az információs aszimmetriából eredő banki kockázatot csökkentheti. A fedezet nyújtása azonban növeli a hitel költségét is, mert az további jogi és adminisztratív költségekkel jár. Chen (2006) elemzése szerint a KKV-tulajdonosok ingatlantulajdona az egyik fontos fedezeti forrás. Abban az esetben, ha recessziós időszak van, az ingatlanárak nagy valószínűséggel csökkennek, így a hitelfelvevő kisebb eséllyel tud új fedezetet bevonni, amely a fedezet likvidálásához vezethet. Az ingatlanárak prociklikus jellege és a nem hatékony likvidálási folyamat tovább mélyítheti a recessziót. Fontos, hogy a fedezet mennyi idő alatt értékesíthető és milyen értékkel bír, hiszen a megállapított érték (például értékbecslő által) nem feltétlenül esik egybe a valós piaci értékkel.

A nem megfelelő hitelkínálatot az is kiváltja, hogy a kisebb vállalkozásokat monitorozni, a megfelelő információkat róluk beszerezni nehézkesebb. Míg egy nyilvános, tőzsdei társaságnak minden mozzanata pontosan dokumentált és a befektetők által hozzáférhető, addig KKV-k esetében ez sokkal korlátozottabb. Természetesen a KKVkról is hozzáférhetők adatok, azonban ezek minősége problémás lehet a nem megfelelő könyvelési és nyilvántartási rendszerek miatt. Másik kérdés a mérethatékonyság, hiszen közel sem mindegy, hogy az energiát egy kis cég hiteligénylésébe, vagy egy nagyvállalat finanszírozásába fekteti, azaz a fajlagos költségráfordítás a meghatározó. A KKV-k esetében azzal a problémával is meg kell küzdeni, hogy sok közülük fiatal társaság, így nem rendelkezik megfelelő múlttal, amelyből a jövőre vonatkozóan következtetést vonhatna le a hitelező.

Bár az utóbbi években a finanszírozási kérdések háttérbe szorultak a KKV-k életében, mégis felmerült két olyan faktor, amely ronthatja a vállalkozások hitelhez való hozzájutását. A banki szektor magas koncentrációja - amikor a piac nagy részét mindössze néhány bank kontrollálja - a KKV-k hitelezésből való kiszorulását vonja maga után. Az utóbbi évek európai banki konszolidációját megfigyelve ez valós problémát jelenthet a kisebb társaságok életében. A másik tényező az ingatlanárak potenciális esése, amely visszavetheti a KKV-k finanszírozását, ugyanis sok társaság az ingatlanját ajánlja fel fedezetül a hitelért cserébe (Chen 2006; Ryan 2014). 
A fenti problémák egy részét, az információs aszimmetria részbeni feloldását a regionális bankok tudják megvalósítani. A helyi bankok erősebb kapcsolatban vannak a helyi KKV-kal, és így a szükséges információ gyorsabban, olcsóbban beszerezhető. Az EIB olasz példán történt megállapítása szerint a helyi bankok jobban ismerik az adott régió jellegzetességeit, valamint a kapocs is erősebb a bank és a hitelfelvevő vállalkozás között (Lang et al. 2016).

\section{A hitelgarancia és intézménye}

A hitelgarancia-szerződés keretében a garanciát vállaló intézmény készfizető kezességgel vállal a pénzintézet felé az adott vállalkozásnak nyújtott hitel tekintetében. Ennek igénybevétele esetén a bank alacsonyabb kockázatot fut, hiszen az ügyfél esetleges nem-teljesítése esetén a garanciát nyújtó intézmény áll helyt a bank irányában a kintlévőség előre meghatározott mértékéig.

A hitelgarancia-alap független, harmadik szereplő a bank és a hitelfelvevő között, amely hitelfelvevő nem rendelkezik minden olyan kitétellel, amely a bank számára szükséges. A garanciaalap így a bank számára egyfajta biztonságot jelent, valamint áttételesen lehetővé teszi a vállalkozás számára, hogy hitelt kapjon. A garanciaintézmények általában állami szerepvállalás mellett jönnek létre, mind a fejlett, mind a fejlődő piacok esetében. Általában nonprofit intézmények, de van egyfajta kötelezettségük az önfenntartásra.

A garanciaintézmények a tőkéjükkel szemben akár annak többszöröséért is garanciát biztosítanak, így a tőkeáttételük elérheti a 20-25-ös értéket is (Davies 2007; Levitsky 1997). A garancia mértéke általában a hitel 30-80 százaléka között mozog. Egy megfelelően múködő garanciaalap öt év múködés után elérheti az ötszörös tőkeáttételt, majd körülbelül 7-10 év múködés után a tízszerest. Amennyiben a viszontgarancia is engedélyezett (mint például Japánban vagy Németországban), a tőkeáttétel mértéke meghaladhatja a 20-as értéket is (O'Bryan 2010). A hitelgarancia-program a legtöbb hitelre kiterjeszthető, ami érintheti új vállalkozások alapítását, gépek, berendezések beszerzését vagy a működő tőke kiegészítését is, de ebben az egyes országok és az egyes garanciaintézmények között lehet eltérés.

A garancia biztosítása több módon történhet: retail- vagy egyedi, portfólió- és wholesale-rendszerben is. A retail-, azaz egyedi rendszerben az egyes cégeket és hiteligényeiket, projektjeiket egyenként értékelik, majd döntenek a garancia megadásáról. Ez az eljárás jelentős költséget és munkaórát emészt fel. A portfóliószintű garancia esetében hasonló hiteleket egyként kezelnek, és így döntenek a garancia kiadásáról, azaz ebben az esetben a banki adminisztrációt nem terhelik az egyedi vizsgálatok és a jóváhagyási procedúra. A bank a garanciaszervezettel előre rögzített keretrendszer alapján maga dönt arról, hogy mi kerül a portfólióba. A wholesale-rendszerben nincs közvetlen kapcsolat a hitelgarancia intézménye és a hitelező/hitelfelvevő között. 
A hitelgarantőr feladata, hogy garanciát szolgáltasson nem banki közvetítőnek, erre tipikus példa Olaszország Központi Garanciaalapja (Central Guarantee Fund, Italy).

Az adós hitelminősítése alapesetben a hitelező feladata, és ez hitelgarancia esetében sincs máshogy, annak ellenére, hogy a hitelgarancia vállalója és a hitelező is elláthatja ezt a feladatot. Alapvetően a hitelezőnek van meg a megfelelő infrastruktúrája a folyamat levezényléséhez. Ugyanakkor a hitelgarancia nyújtója és a hitelintézet között felléphet a megbízó-ügynök probléma, ami túlzott kockázatvállalást vagy a hitelminősítési folyamat alultervezését vonhatja maga után (Chatzouz et al. 2017).

A hitelgarancia alkalmazásával a bankok bizonyos esetekben csökkenthetik RWA-kitettségüket. A Basel III és a CRR/CRD-szabályozás keretében a bankok csökkenthetik a hitelgaranciával fedezett hitelek utáni tőkekövetelményt. Mindezt a CRR/CRD vagy az EBA szabványai határozzák meg. Mindez a válság után lett igazán érdekes a bankok szempontjából, hiszen a pénzintézetek komoly tőkeleírásokkal szembesültek, illetve az elmúlt 10 évben a szabályozás és a tőkekövetelménye is szigorodtak, aminek következtében a banki működés biztonságosabb, de komplikáltabb és költségesebb is lett.

A nyugat-európai hitelgarancia-intézmények ismérve, hogy az 1990-es évek közepén kezdték őket megalapítani, részben állami tulajdonúak, nonprofit társaságok, de van egyfajta kötelezettségük az önfenntartásra - csak Franciaországban és Olaszországban találkozhatunk teljesen privát garanciaintézményekkel) -, továbbá nincs tiltás a tőkeáttételükre vonatkozóan, és adómentességet élveznek. Leginkább a KKV-kat célozzák meg, azzal a céllal, hogy növeljék a hitelezési aktivitást ebben a szegmensben. Garanciát bankok, lízingcégek és egyéb pénzügyi intézmények felé vállalnak, főleg forgóeszközhitel, beruházás és kereskedelmi hitel esetében. A garanciához kapcsolódó díjakat a hitelfelvevő fizeti, és az a hitel összegétől függ. A kockázat vállalása 34 és 81 százalék között szóródik, és 10-15 évre szólhat. A veszteség megosztása általában pari passu (Chatzouz et al. 2017).

A hitelgaranciának természetesen díja is van, amely általában egy éves díjból és egy upfront-díjból tevődik össze, amely díj tükrözi a projektek kockázatosságát is. A garantőr adminisztrációs díjat is felszámolhat, valamint meghatározhatja, hogy a díjakat ki viselje, a hitelező, vagy a hitelfelvevő. A fentihez azonban kapcsolódik, hogy nem minden esetben valósul meg kockázati alapú árazás, így Magyarországon sem ez a gyakorlat.

A garanciaprogramokat vizsgálhatjuk specifikus országok és az EU szemszögéből is. Utóbbi esetében a COSME, az SME Initiative és az Innovfin programok hivatottak elősegíteni a KKV-k finanszírozását. Kisebb mértékben a Cultural and Creative Sector Guarantee Facility, amely olyan KKV-nak nyújt lehetőséget, amelyek a kulturális és kreatív szektorban érdekeltek, valamint az EaSI - Employment \& Social 
Entrepreneurship, amely garanciaprogramjában a munkaerőpiac erősítését, az EU-n belüli mobilitás megteremtését túzte ki célul.

A COSME összesen 2,3 milliárd eurós büdzsével fut 2020-ig. Célja, hogy a KKV-k könynyebben jussanak forráshoz, elősegítse a vállalkozói kedvet, biztosítsa a megfelelő környezetet az új vállalatok elindításához és növekedéséhez. A program keretében a garancia mértéke a tőketartozás maximum 50 százalékig terjedhet, és maximum 249 főt foglalkoztató társaság veheti igénybe, azaz a mikro-, kis- és közepes vállalkozások is részt vehetnek benne. Nagy előnye a programnak, hogy díjmentes, valamint hogy csökkenti a bank RWA-kitettségét, amennyiben nem feltételes a garancia. Utóbbi azért fontos, mert egy kiinduló állapothoz viszonyítva a garanciák igénybevétele révén több vállalkozást is tud finanszírozni egy pénzintézet ahhoz képest, mintha nem venné igénybe ezt a lehetőséget.

Az Innovfin célja, hogy az innovatív KKV-k megfelelő forráshoz jussanak. A program 25 ezer és 7,5 millió euró közötti hitelek esetében alkalmazható (1 és 10 év közötti futamidővel), maximum 499 főt foglalkoztató társaság esetében. Olyan KKV-knak nyújt hitelgaranciát, amelyek valamilyen innovatív terméket fejlesztenek, vagy gyorsan növekszenek (a foglalkoztatottak vagy a bevétel 20 százalékkal nőtt az elmúlt 3 évben éves szinten). A program költsége 0,5-0,8 százalék évente, a kihelyezett hitel maximum 50 százalékát fedezi veszteség esetén, valamint szintén csökkenti a bankok RWA-kitettségét. A kezdő, „start-up” vállalkozások esetén a hitelgarancia abból a szempontból érdekes, hogy a hitelhez való hozzájutást az is nehezíti, ha a cégnek nincs előélete, úgynevezett „track record-ja”.

A fenti garanciaintézmények ismérve, hogy nemzetközi szintéren működnek, szemben az egyes országok garanciaintézményeivel, amelyek inkább csak az adott ország határain belül végeznek tevékenységet. A nemzetközi hitelgarancia-szolgáltatásnál a legfontosabb szereplő az EIF, az EIB Group része. Ide az SME Initiative és az Innovfin, valamint a COSME programok tartoznak. Az EIF KKV-k hiteleihez és lízingjeihez nyújt garanciát, valamint viszontgaranciát nyújthat a helyi hitelgarancia-intézmények portfóliójához.

\section{A hitelgarancia intézménye és az európai gyakorlat}

A hitelgarancia intézménye a külső finanszírozást érintő anomáliákat nem oldja fel teljes egészében, és így a probléma gyökerét sem tudja kezelni, ám hozzájárulhat a hitelezési piac zavartalanabb működéséhez. Az állami szerepvállalás mellett a hitelgarancia intézménye az az eszköz, amely lehetőséget biztosítana arra, hogy a vállalkozások negatív gazdasági hangulatban is hozzájuthassanak megfelelő forrásokhoz. Ezáltal végső soron a gazdasági visszaesés mértékét is tompítani lehetne. A kérdés, hogy valós feltételezés-e az, hogy a hitelgarancia léte segít tompítani a gazdasági visszaesést? 
A garanciaalapok KKV-k körében hangoztatott fontosságát emeli ki, hogy 50 ezer olasz vállalati hitelt megvizsgálva azt lehetett tapasztalni, hogy a KKV-k esetében, arányában több fedezetet kérnek a bankok, mint a nagyvállalatok hitelezése során (Pozzolo 2004). Az is igaz továbbá, hogy a nagyobb cégek sokkal könnyebben jutnak külső forráshoz, így a KKV-szektor a mérete miatt (és így a kockázatossága miatt) is hátrányban lehet (Beck et al. 2005). A mérethatékonyság itt is fontos kérdéskör, hiszen egy bank szempontjából nem mindegy, hogy egy kis cég kis projektjét finanszírozza, vagy egy multinacionális vállalatot.

Az EIB elemzése megemlíti, hogy a garanciaprogram csak abban az esetben lehet előnyös a gazdaság szempontjából, ha körültekintően valósítják meg (Kraemer et al. 2017). Mivel a tulajdonosok között a legtöbb esetben fellelhető az állam, így az esetleges csődöt végső soron bizonyos mértékig az adófizetők viselik. Ez pedig a 2008-as válság óta rendkívül kényes kérdés, sőt az EU tiltja is a „bail-out” intézményét, azaz azt, amikor a csődbe jutott vagy annak szélén álló pénzintézetet az állam menti ki. 2008 és 2012 között az EU 568 milliárd eurót költött csődközeli bankok megmentésére, amit az adófizetők álltak. Helyette a „bail-in” eljárást kell alkalmazni, ennek keretében a részvényesek, kötvényesek és végső soron a legnagyobb betétesek tőkésítik fel a pénzintézetet. Ennek első megvalósult formája a ciprusi válság levezénylése volt 2012/2013 folyamán.

Az utóbbi években jelentősen csökkent a garanciaprogramok adminisztratív terhe, valamint több helyen is gyorsították az eljárást, így még mindig ezek a programok tekinthetők az elsődleges állami eszköznek a KKV-k forráshoz jutásának megkönynyebbítése szempontjából. Mindez annak ellenére alakult így, hogy a „moral hazard” rémképe továbbra is feltűnik. Ez a veszteségmegosztás („loss sharing”) és a fedezettség arányának („coverage ratio”) pontos definíciójával elkerülhető, csökkenthető. A veszteség megosztása lehet pari passu, ahol a veszteség mértéke az összegtől függetlenül fix. A behajtott adósság az előre meghatározott megosztás szerint kerül allokálásra a hitelező és a garancia biztosítója között. Az alárendelt adósság esetén először a hitelezőt elégítik ki, majd utána következik a garantőr. Portfólió-szinten a „first-loss”-garancia esetében a csőd teljes terhét a veszteség előre meghatározott részéig vállalják, míg a „second-loss"-garancia esetében a garantőr csak a veszteség második részét fedezi. Továbbá, amennyiben a fedezettség aránya magas, a hitelező ösztönzést érezhet arra, hogy elhanyagolja az adós monitorozását, kockázatainak megítélését.

Az OECD megállapítása szerint a garanciaprogramok nagy többségben a fiatal és innovatív vállalatokat célozzák azért, hogy így csökkentsék a munkanélküliséget és növeljék a termelékenységet (Kraemer et al. 2015; Kraemer et al 2017). A garanciaintézmények előnye, hogy harmadik szereplőként vannak jelen a hitelezési eljárásban, így a forrás folyósítását végső soron egy piaci alapon múködő intézmény bírálja el, a bank. A hitelgarancia intézményei a legtöbb esetben az országhatárokon belül 
végzik tevékenységüket, így a geográfiai eloszlás megfelelő lesz, és a régiós bankok sokkal hatékonyabban tudják kiszolgálni az adott területen múködő társaságokat.

Mint látjuk, a hitelgarancia segítségével transzferálható a nemfizetési kockázat (és ilyen formában hasonlatos a derivativ, határidős termékekhez, melyek szintén a kockázat megfelelő kezelése miatt jöttek létre), de emellett iparági és geográfiai diverzifikációt is megvalósithat. Erősödhet továbbá a kockázatelemzés, hiszen abba a hitelgarantőr is becsatlakozik, valamint a szabályzói arbitrázs is létrejöhet, hiszen a hitelgarancia segítségével lehetővé válhat, hogy a hitelező megfeleljen a szabályzói követelményeknek.

Az EU-ban és a környező országokban fellelhető garanciaintézmények múködését, adatait az AECM (European Association of Guarantee Institutions) fogja össze. A legfrissebb adatok szerint az EU-n belül a GDP arányában Olaszországban, Portugáliában és Magyarországon a legmagasabb a kibocsátott garanciák értéke. Míg az EU országainak nagy részében a kibocsátott garanciák a GDP 0,2-0,5 százalékát teszik ki, addig az első három ország esetében ez az arány 1,7-2 százalék között mozog (5. ábra).

\section{5. ábra \\ Az adott országban kibocsátott hitelgaranciák a GDP százalékában 2015 és 2016 között}

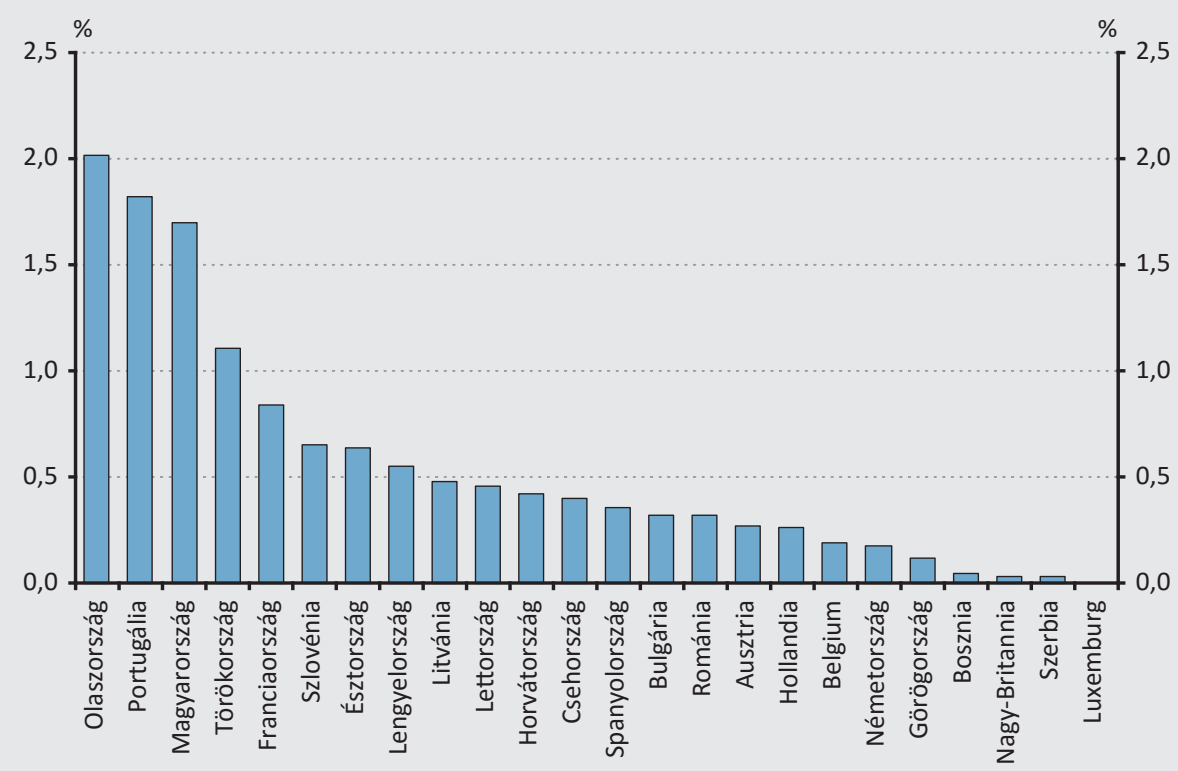

Forrás: AECM (Kraemer et al. 2015 és Kraemer et al. 2016) 
- Az AECM 2016-os adatai szerint a múlt évben a 42 tag körülbelül 30 milliárd eurónyi garanciát helyezett ki 26 európai országban, amelyből 2,8 millió darab KKV részesült, és több mint 400 ezer új vállalkozás jött létre. Átlagosan a bankok a kockázat 30 százalékát futották, míg a maradékot a hitelgarancia-intézmények fedezték (Kraemer et al. 2017).

A hitelgarancia-programokat az utóbbi években jelentősen kiterjesztették, főleg a válságra adott reakció miatt. Az országhatárokon belül múködő garanciaintézmények a válság alatt növelték aktivitásukat, de a KKV-k oldaláról rendkívül alacsony kereslet mutatkozott a hitelek iránt, így a recesszió hatását ezeknek a programoknak nem sikerült enyhítenie. Főleg a forgóeszközhitelekben erősítettek az intézmények, mivel a válság eredményeképpen a társaságok itt szorultak a legnagyobb segítségre. A hitelgarancia-nyújtás aktivitásának növekedése azonban az intézményeket feladat elé is állította, hiszen ehhez több tőke volt szükséges. A múltbeli adatok azt mutatják, hogy a garanciaintézmények 22 százaléka megkapta a szükséges tőkét, 50 százaléka pedig csak átmenetileg tudhatta azt magáénak (Chatzouz et al. 2017).

Az EIB legfrissebb felmérése szerint (Chatzouz et al. 2017) az EU megkérdezett bankjainak 91 százaléka használja a hitelgarancia intézményét, ennek aránya azonban a bankok összes KKV hiteléhez képest elenyésző: a bankok mindössze 20 százaléka nyilatkozott úgy, hogy a teljes KKV-hitelállományuk legalább 10 százalékához köthető hitelgarancia. A bankok leginkább azért vesznek igénybe hitelgaranciát, mert a KKV-k fedezete nem megfelelő, és az átlagnál kockázatosabb, de mindemellett az is fontos szempont, hogy a hitelgarancia igénybevételével a kockázatos eszközök csökkenthetők, és ez a válság után megvalósult szigorúbb szabályozások közepette kedvező helyzetbe hozza a pénzintézeteket.

A felmérés szerint a bankok arról is meg vannak győződve, hogy a garanciaintézmények hirdetései nem irányulnak a KKV-szektor felé, így a potenciális hitelfelvevők nem is tudják, hogy milyen lehetőségük lenne abban az esetben, ha nincs megfelelő fedezetük, vagy a projektjük kockázatos.

A bankok 60 százaléka szerint a hitelgarancia intézményének nincs hatása arra, hogy egy adott hitel nem-teljesítő lesz vagy sem, 35 százalékuk szerint pedig úgy véli, hogy a garancia növeli a hitel bedőlésének valószínűségét. Cowan et al. (2015) szerint a garanciaprogramban részt vevő társaságok hitelei 1,67 százalékkal nagyobb eséllyel lesznek nemteljesítők az első 24 hónapban a garanciával nem rendelkezőkhöz képest, ám azt a szerzők is elismerik, hogy a hitelgarancia segíti a KKV-k finanszírozását.

Az EU-ban kevés tanulmány áll rendelkezésre a hitelgaranciának a gazdaságra és KKV-k hitelezésére gyakorolt hatásáról. Ennek az az oka, hogy rendkívül kevés a megbízható és elérhető adat. Az Európai Bizottság és az EIF 2015-ben végzett kutatása 
a vállalkozásokra, különösen a kis- és középvállalkozásokra (KKV-kre) vonatkozó többéves program gazdasági hatásait vizsgálta a programban részt vett és az abban nem szereplő kontrollcsoport között a 2005 és 2012 közötti időszakban, „difference in difference" módszerrel (Asdrubali - Signore 2015). A vizsgálat 10 keletközép-európai országra vonatkozott, 1 és 250 fö közötti foglalkoztatottal rendelkező, 0 és 10 év közötti vállalatokra. Megállapításuk szerint a programban részt vevő KKV-k az első öt évben 17,3 százalékkal növelték a foglalkoztatottak számát, és bevételük a kontrollcsoporthoz viszonyítva 19,6 százalékkal nőtt. A foglalkoztatás növelése leginkább Románia és Csehország esetében volt szignifikáns. Az elemzésből az is kiolvasható, hogy a mikro- és a fiatal társaságok szerezték a legnagyobb előnyt a program keretében: míg a legkisebb vállalatok a foglalkoztatottak számát 18 százalékkal, forgalmukat közel 25 százalékkal tudták növelni, ugyanez a két mutató a fiatal, azaz 5 év alatti társaságok esetén 34 és 27 százalék volt.

Ugyanakkor rövid távon (0 és 3 év között) a programban részt vevő társaságok termelékenysége csökkent (9-11 százalékkal), amely különbség csak középtávon tűnt el. A szerzők szerint ennek oka a garancia után kapott tőke és forrás esetleges félreallokálása. Továbbá mivel a garancia előtti két évben az ilyen társaságok nagy része nem rendelkezett hitellel, a hátrányt a megváltozott helyzethez való alkalmazkodás is okozhatta, így például az újonnan fennálló tőkeáttétel menedzselése.

A hitelgarancia-intézmények múködése és megítélése azonban nagyban függhet a gazdaság általános teljesítésétől is. A lengyelországi LDF-garancialap a gazdaság gyors növekedési szakaszában (1998-2000) számos garanciát biztosított, amelyek jól teljesítettek. A 2000-es évek utáni recesszióban, ahogy a nem-teljesítési ráták nőttek, megtagadta az ajánlatok befogadását, így nem is tudott abban érdekelt lenni, hogy a gazdasági visszaesést tompítsa (Bennett et al. 2005).

A hitelgaranciák mennyisége a GDP-hez viszonyítva Olaszországban a legmagasabb, valamint itt múködött a legtöbb hitelgaranciát kapott KKV is, nevezetesen több mint 1,3 millió darab 2016-ban az AECM adatbázisa szerint (Kraemer et al. 2017). Az olasz KKV-szektort vizsgálva, annak fényében, hogy a hitelfelvevő milyen biztosítékot szolgáltat, fizikai vagy személyes biztosítékot, mint a hitelgarancia, ahol egy harmadik személy lép közbe csőd/nemteljesítés esetén, a fizikai biztosíték esetében annak a valószínűsége, hogy a hitelfelvevő csődbe megy, nem különbözött nullától (Pozzolo 2004). Így nem igaz az a megállapítás, mely szerint a bankok azért, hogy csökkentsék a "moral hazard” kockázatát, több biztosítékot kérnek (Boot et al. 1991 és 1994). Ezzel szemben a csőd valószínűsége a hitelgarancia esetében pozitív és szignifikáns, vagyis a bankok ösztönzőként használják a hitelgarancia intézményét az erkölcsi kockázat esetében. Fizikai biztosíték esetében pozitív a kapcsolat a bank és a hitelfelvevő viszonya és annak ideje között, míg negatív a hitelgarancia esetében. Azaz azok a hitelfelvevők, akik több mint 20 éve kapcsolatban állnak az adott pénzintézettel, sokkal inkább szolgáltatnak fizikai biztosítékot, már csak azért is, 
mert így arra is nagyobb az esélyük, hogy pénzügyi nehézségek esetén a bank „segítséget" nyújt.

Az elemzés továbbá azt is megállapítja, hogy a bankok a kisvállalatoktól a nagyobb cégekhez viszonyítva több biztosítékot kértek. A cégek legkisebb 20 százalékának fizikai biztosítéka több mint háromszor volt magasabb, mint a legnagyobb cégeké. A hitelgarancia esetében a sáv nem ennyire széles, hiszen ebben az esetben a legkisebb társaságok hiteleinek biztosítéka 1,2-szerese volt a legnagyobbakéhoz viszonyítva.

\section{Konklúzió}

A hitelgarancia intézményeinek az EU-ban működő KKV-k finanszírozásában betöltött szerepe az 1990-es évek közepétől kezdett felértékelődni, ekkor jelentek meg az első ilyen intézmények. Szerepük azért is fontos, mert ellentétben az USA-val, az Európai Unióban a KKV-szektor külső forrásainak megszerzése tekintetében 80-85 százalékban bankokra és banki termékekre támaszkodik (hitel, faktoring, kereskedelmi hitel, stb.) Gazdasági visszaesésben a banki hitelezés dinamikája csökken, mind a hitelfelvevők, mind a hitelnyújtók kockázatkerülőkké válnak. Így a KKV-k nem jutnak megfelelő forráshoz, ami tovább mélyítheti a recessziót, hiszen csökkennek a beruházások, mérséklődik a társaságok profitja, növekszik a munkanélküliség és csökken a fogyasztási hajlandóság. Kérdés, hogy ilyen esetben a hitelgarancia intézménye (amely lehet nemzetközi, vagy országon belüli is) mennyire csökkentheti ezt a visszaesést, mennyire tudja kisimítani azokat a kilengéseket, amelyek az egyes felfelé ívelő gazdasági ciklusokat megszakítják. A nemzetközi tanulmányok és elemzések vegyes képet mutatnak, utóbbi esetben hiányosak is, hiszen ritka a pontos és fellelhető adatforrás.

Az áttekintésből az rajzolódik ki, hogy bár az unióban léteznek nemzetközi megoldások a hitelgarancia intézményére vonatkozóan, az egyes régiók közötti eltérések a helyi, országokon belüli alapok meglétét követelik meg. Az egyes régiók vállalatainak klaszteranalízise azt mutatja, hogy más és más feltételekre kell felkészülni például az igénybe vett finanszírozási forrás vagy a pénzügyi rendszer fejlettsége függvényében.

A 2008-as válság óta a bankrendszer komoly szabályozáson ment keresztül, és múködésük is költségesebb lett. Így a hitelgarancia nemcsak a KKV-szektor könnyebb forráshoz jutását szolgálhatja, hanem a bankok kockázatos eszközeinek csökkentéséhez is megfelelő eszköz lehet, megfelelve a szabályzói követelményeknek. Ugyanakkor a gazdaság általános helyzete hatással van a garancialapok müködésére is, hiszen nagy mennyiségű nem teljesítő hitelek esetében kihátrálhatnak a tevékenységükből ahelyett, hogy tevékenységükkel javítanának a gazdasági helyzeten. 
A KKV-szektor megerősítése több szempontból is éreztetné hatását. Mivel ezek a vállalkozások az unió munkaképes lakosságának körülbelül 70 százalékát foglalkoztatják és a kontinens GDP-jének közel 60 százalékát adják, megerősítésük nagyban javítaná Európa gazdasági helyzetét és kilátásait. A hitelgarancia-intézmények recessziós időszakban történő megnövekedett aktivitása csökkenthetné a KKV-szektor profitjának és múködésének volatilitását, így stabilabbá válhatna a munkaerőpiac helyzete és áttételesen a fogyasztás is, ami a gazdasági növekedés egyik pillére. Emellett kiegyensúlyozottabbá és kiszámíthatóbbá válnának a beruházások, ami szintén a GDP-növekedés meghatározó tényezője.

\section{Felhasznált irodalom}

AECM (2017): Representative of guarantee institutions in Europe - fostering SMEs' growth. www.aecm.eu. Letöltés ideje: 2017. szeptember 13.

Arcand, J-L. - Berkes, E. - Panizza, U. (2012): Too Much Finance? IMF Working Paper, WP/12/161, June.

Asdrubali, P. - Signore S. (2015): The economic impact of EU guarantees on credit to SMEs. Discussion Paper 002. https://ec.europa.eu/info/sites/info/files/economy-finance/dp002_ en.pdf. Letöltés ideje: 2017. szeptember 13.

Banque de France (2017): Adatbázis. www.bach.banque-france.fr/?lang=en. Letöltés ideje: 2017. szeptember 13.

Beck, T. - Demirgüç-Kunt, A. - Maksimovic, V. (2005): Financial and legal constraints to growth: Does firm size matter? The Journal of Finance, 60(1): 137-177. https://doi.org/10.1111/j.1540-6261.2005.00727.x

Bennett, F. - Alan, D. - Harriet, B. (2005): Do credit guarantees lead to improved access to financial services? Recent evidence from Chile, Egypt, India and Poland. Financial Sector Team, Policy Division Working Paper, Department for International Development, London.

Bodnár Katalin - Kovalszky Zsolt - Kreiszné Hudák Emese (2014): A válságokból történő kilábalás és a hitelezés kapcsolata. Hitelintézeti Szemle, 13. évf. 4: 57-85.

Boot, A. W. A. - Thakor, A. V. (1994): Moral Hazard and Secured Lending in an Infinitely Repeated Credit Game. International Economic Review, 35: 899-920.

https://doi.org/10.2307/2527003

Boot, A. W. A. - Thakor, A. V. - Udell, G. F. (1991): Secured lending and default risk: Equilibrium analysis, policy implications and empirical results. Economic Journal, 101: 458-472. https://doi.org/10.2307/2233552 
Cecchetti, S. G. - Kharroubi, E. (2012): Reassessing the impact of finance on growth. BIS Working Papers No. 381.

Chatzouz, M. - Gereben, Á. - Lang, F. - Torfs, W. (2017): Credit guarantee schemes for SME lending in Western Europe. EIB Working Paper (2017/02)

Chen Y. (2006): Collateral, loan guarantees, and the lenders' incentives to resolve financial distress. Quarterly Review of Economics and Finance, 46: 1-15. https://doi.org/10.1016/ j.qref.2004.10.001

Cowan, K. - Drexler, A. - Yańez, A. (2015): The effect of credit guarantees on credit availability and delinquency rates. Journal of Banking and Finance, 59, 98-110.

https://doi.org/10.1016/j.jbankfin.2015.04.024

Davies, I. (2007): People's Republic of China: Development of small and medium-sized enterprise credit guarantee companies. Asian Development Bank.

ECB (2017a): European Central Bank: Survey on the access to finance of enterprises in the euro area (2009-2017). https://www.ecb.europa.eu/stats/ecb_surveys/safe/html/index. en.html. Letöltés ideje: 2017. november 17.

ECB (2017b): European Central Bank: Securities issues (Kötvénykibocsátási adatbázis). https://www.ecb.europa.eu/stats/financial_markets_and_interest_rates/securities_issues/ html/index.en.html. Letöltés ideje: 2017. november 15.

Evans, D.S. - Jovanovic, B. (1989): An estimated model of entrepreneurial choice under liquidity constraints. The Journal of Political Economy, 97(4): 808-827.

https://doi.org/10.1086/261629

Farhi E. - Tirole J. (2011): Collective moral hazard, maturity mismatch and systemic bailouts. American Economic Review 102(1): 60-93. https://doi.org/10.1257/aer.102.1.60

Firoozmand, S. - Haxel, P. - Jung, E. - Suominen, K. (2015): State of SME finance in the United States in 2015. TradeUp Capital Fund and Nextrade Group, LLC, March.

Holmstrom, B - Tirole, J. (1997): Financial Intermediation, Loanable Funds and The Real Sector. The Quarterly Journal of Economics, 112(3): 663-691.

https://doi.org/10.1162/003355397555316

Khwaja, A.I. - Mina, A. (2005): Do lenders favor politically connected firms? Rent provision in an emerging financial market. The Quarterly Journal of Economics, 120(4): 1371-1411. https://doi.org/10.1162/003355305775097524

Kraemer-Eis, H. - Lang, F. - Torfs, W. - Gvetadze S. (2015): European Small Business Finance Outlook. EIF Research and Market Analysis, Working Paper 2015/32. 
Kraemer-Eis, H. - Lang, F. - Torfs, W. - Gvetadze, S. (2016): European Small Business Finance Outlook. EIF Research and Market Analysis, Working Paper 2016/35.

Kraemer-Eis, H. - Lang, F. - Torfs, W. - Gvetadze S. (2017): European Small Business Finance Outlook. EIF Research and Market Analysis, Working Paper 2017/43.

Kuniyoshi, S. - Tsuruta, D. (2014): Adverse selection and moral hazard in the Japanese public credit guarantee schemes for SMEs. CEPR's Policy Portal.

Lang, F. - Signore, S. - Gvetadze S. (2016): The role of cooperative banks and smaller institutions for the financing SMEs and small midcaps in Europe. EIF Research and Market Analysis, Working Paper 2016/36.

Levitsky, J. (1997): Credit guarantee schemes for SMEs: An international review. Small Enterprise Development, 8(2): 4-17. https://doi.org/10.3362/0957-1329.1997.013

Mina, A. - Lahr, H. - Hughes, A. (2013): The demand and supply of external finance for innovative firms. Industrial and Corporate Change, 22(4): 869-901. https://doi.org/10.1093/icc/dtt020

Moritz A. - Block H. J. - Heinz A. (2015): Financing patterns of European SMEs: An empirical taxonomy. EIF Research \& Market Analysis, Working Paper Nr. 30.

Murray, G. C. - Lott, J. (1993): Have UK venture capitalists a bias against investment in new technology-based firms? Research Policy, 24(2): 283-299. https://doi.org/10.1016/00487333(93)00767-N

O'Bryan W. E. (2010): An analysis of small business loan guarantee funds. Thesis. Retrieved from: https://digitalcommons.unl.edu/cgi/viewcontent.cgi?article=1003\&context=arch_ crp_theses. Letöltés ideje: 2017. szeptember 13.

Pozzolo, A. F. (2004): The role of guarantees in bank lending. EFMA 2004 Basel Meeting Papers. https://doi.org/10.2139/ssrn.498982

Ryan, R. M. - O'Toole, C. M. - McCann, F. (2014): Does bank market power affect SME financing constraints? Journal of Banking \& Finance, 49(December): 495-505. https://doi.org/10.1016/j.jbankfin.2013.12.024

Stiglitz, J.E. - Weiss, A. (1981): Credit rationing in markets with incomplete information. The American Economic Review, 71(3): 393-410.

WSBI-ESBG (2017): Financial systems in Europe and in the US: Structural Differences where banks remain the main source of finance for companies. Research Paper, www.wsbiesbg.org. Letöltés ideje: 2017. május 3. 